\title{
TRANSFORMATION OF LITERARY IMAGERY IN RUSSIAN TRANSLATION CONTEXT
}

\author{
Irina Budanova ${ }^{1 *}$, Kristina Klasnja $^{2}$ \\ ${ }^{1}$ Assoc. Prof., Peoples' Friendship University of Russia (RUDN University), RUSSIA, \\ budanovaib@pfur.ru \\ ${ }^{2}$ Assoc. Prof., Peoples' Friendship University of Russia (RUDN University), RUSSIA, \\ akhninakv@rudn.ru \\ ${ }^{*}$ Corresponding Author
}

\begin{abstract}
The article focuses on the shift of the semantic accents in the process of translation on the example of the main character. The shift of the accents influences on the main hero's perception by a reader. It takes place in case of replacement or removal of particular words which are core for the text. The present article shows that the quantity characteristics of the basic concepts in the original and translated texts allow confirming the shift of the semantic accents. The changes in percentage terms of the usage of the concept frequency permit to evaluate adequately and to analyze the hero's transformation by a translator. From the standpoint of comparative linguistics and translation, it is interesting to analyse the work of Ostrovsky as a translator with the text of the play in terms of modifications.

Our hypothesis is empirically to find out how much the translator's intent is confirmed by the nature of the translation of the play, i.e. in what way, to what extent and due to which it was possible to shift the semantic emphasis in the image of the main character. For this reason, a need arises to compare the Italian original with the Russian translation. To test the hypothesis, we used statistical methods based on functional and comparative approaches as well as the method of scientific description.

Ostrovsky's attention to Giacometti's play was explained by a psychological elaboration of a character's image, the character that is endowed with moral qualities. There was a process of creative interaction of artistic principles of the national Russian theatre and the European one in Ostrovsky's work. This process led the playwright to creating the artworks that are remarkable for their acute moral and social problems and deep psychological discoveries.
\end{abstract}

Keywords: translation, comparative studies, national character, national-cultural specificity.

\section{INTRODUCTION}

A.N. Ostrovsky is the creator of the Russian national theatre, but his activity as a translator has never been studied and is not known to the general reader. A concordance will help us to explore the significance of $A$. $\mathrm{N}$. Ostrovsky's translation activity and evaluate his contribution to the development of problems related to translations of dramatic texts. In this article we shall consider the practical application of the concordance dictionary being compiled using as an example the translation of the play The Family of the Criminal.

In 1870, A.N. Ostrovsky translated one of the most famous Italian melodramas, Civil Death (La morte civile, 1861), written by playwright Paolo Giacometti. He entitled the translation The Family of the Criminal.

\subsection{The Plot of the Play}

The main character of the play - Corrado - was sentenced to life imprisonment for the murder of his wife's brother. After thirteen years he escaped from prison with the aim of returning his family. He finds his wife 
Rosalia working as a governess for Emma, daughter of a doctor. But, in fact, Emma is Ada, daughter of Rosalia and Corrado. According to the law, after Corrado's arrest, his wife and child were left without civil and social rights and without any means of survival. Therefore, Dr. Palmieri gave Ada for his dead daughter Emma, and took Rosalia as a governess to his house to save them from shame. Corrado wants to bring his family back but understands that the only thing he can do for the happiness of his wife and daughter is to commit suicide.

\subsection{Justification of Scientific İnterest}

From the standpoint of comparative linguistics and translation, it is interesting to analyse the work of Ostrovsky as a translator with the text of the play in terms of modifications. First of all, Ostrovsky changed the title: the drama was entitled The Family of the Criminal instead of Civil Death. Due to this, Ostrovsky deepened the civil conflict: it was extended to the whole family of Corrado.

In a letter of the 28th April, 1870, Ostrovsky writes: "Civil Death must be radically changed; Corrado should be made a political criminal rather than a murderer" (Ostrovsky, T. 11). The above facts led to the hypothesis: to empirically find out how much the translator's intent is confirmed by the nature of the translation of the play, i.e. in what way, to what extent and due to which it was possible to shift the semantic emphasis in the image of the main character. For this reason, a logical need arises to compare the Italian original with the Russian translation.

\section{MATERIALS AND METHODS}

To test the hypothesis, we used statistical methods based on functional and comparative approaches as well as the method of scientific description. The unit of analysis is a lexical-semantic field (LSF), i.e. a set of lexical units expressing one concept and united by a common content. Modelling a lexical-semantic field makes it possible to imagine a certain concept formed in the original text and modified in the translation.

In the process of testing the hypothesis, given that the salience of the expressed meanings is also determined by the frequency of use of the lexical units expressing them (Wierzbicka, 1997: 11-15), the problem arose of counting the lexical-semantic variants of the lexical-semantic field "law" (as a broader semantic version of "civil"), among which we have identified: "killer", "law", "justice", "court", "guilt" and "family", including the concepts of the emotional sphere such as "love", "happiness", "mercy" and terms of kinship such as "husband", "wife", "father", "mother", "daughter". While solving this problem, we turned to various computer programmes, but among them we did not find any fully licensed and recognised by the scientific community, so we used the Microsoft Word "Find" feature.

\section{RESULTS}

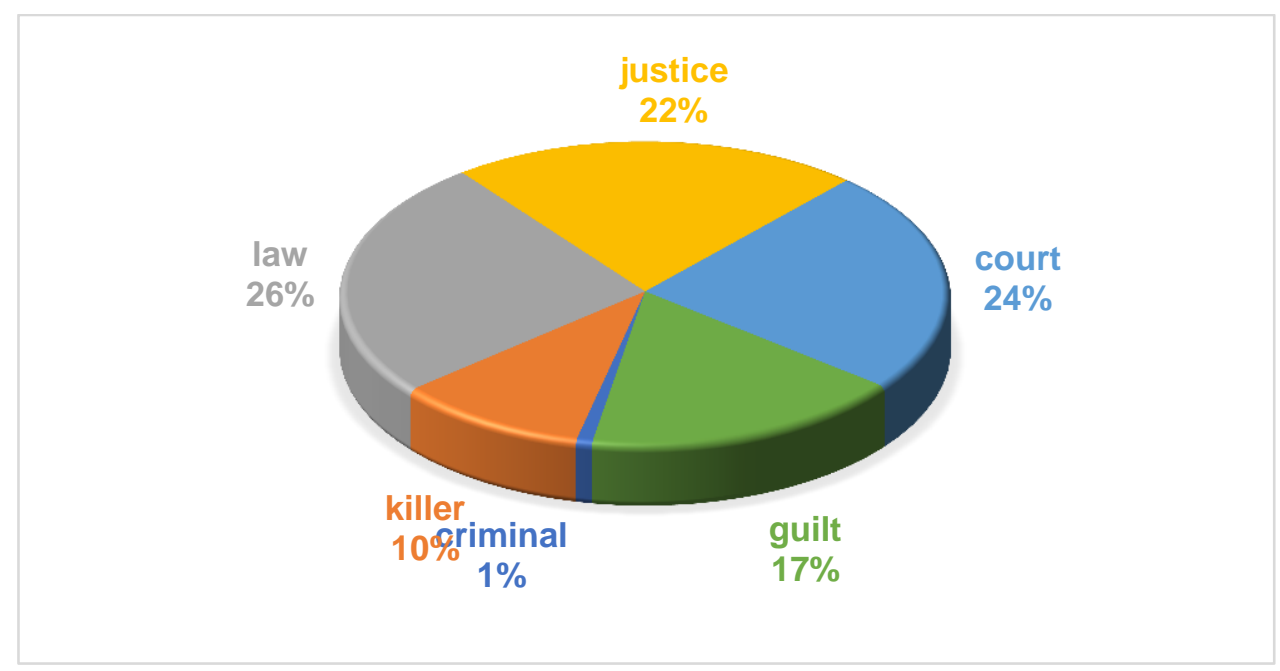

Figure 1: LSF "Law" (Italian text) 


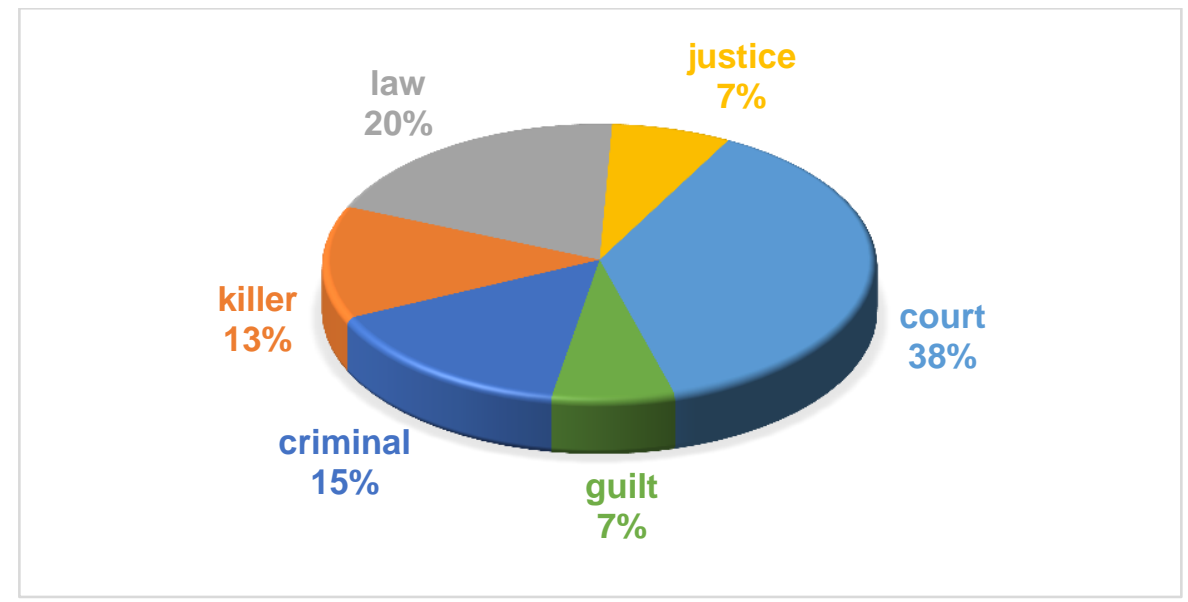

Figure 2: LSF "Law” (Russian text)

As can be seen, the semantic centres in the original are focused on the LSV "legge" ("law") and "diritto" ("justice") ( $44 \%$ vs. $27 \%$ ), whereas the Russian translation highlights the meanings "cyд" (sud, "court"), (38\% vs. $22 \%$ ), and the LSV "преступник" (prestupnik, "criminal, delinquent, offender, prisoner") occupies $15 \%$ of the total field vs. $9 \%$ of the frequency of its use in the original.

The analysis of the semantic field "family" did not reveal significant differences in the percentage ratio in the accentuation of meanings, which was quite predictable when taking into account the terms of kinship, because this group of words implies only nominations without any connotations. However, emotional vocabulary was of interest as a probable sphere of modifications.

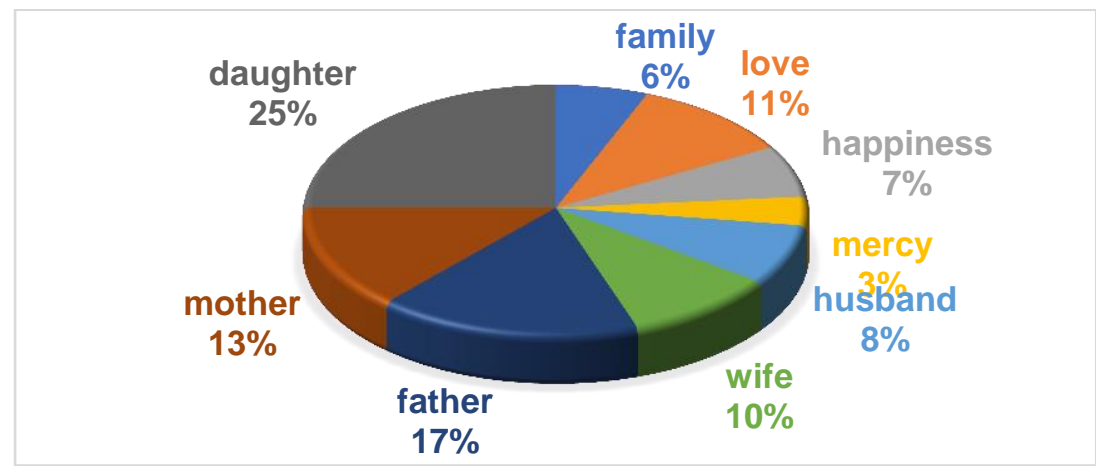

Figure 3: LSF "Family" (Italian text)

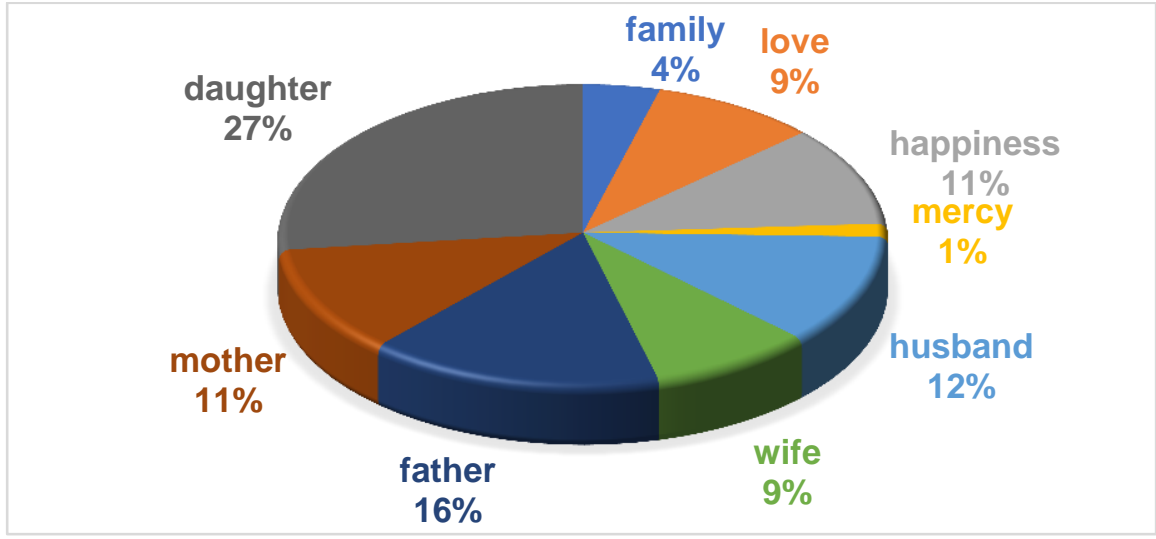

Figure 4: LSF "Family" (Russian text)

Having obtained quantitative indicators, given that numerical indications are not a self-valuable source and should be considered in the context of a thorough semantic analysis (Wierzbicka, 1997: 11-15), we turned to 
their contextual use. If we analyse, for example, the LSV "убийца" (ubijca, "killer") (9\% in the original vs. 13\% in the translation) and context, we will see the following picture:

the words "sicario" ("hired killer"), "omicida" ("killer"), "uccidere" ("to kill") were removed from the text, but the verb "убить" (ubit', "to kill") is used in the translation as a description of the actions of external forces ("убило rope", (ubilo gore, "grief killed"), “голод убил" (golod ubil, "hunger killed")), and paraphrases adding melodramatics ("моё лезвие прокололо" (moyo lezvie prokololo, "my blade pierced"), "орошён кровью невинного" (oroshyon krov'yu nevinnogo, "bedewed with the blood of an innocent")) were replaced by the cold fact: "убил" (ubil, killed). Of the 13 cases when the main character was called "killer" in the original text, Ostrovsky removed 7; therefore, the semantic emphasis was shifted by almost half. For example, in a conversation between Corrado and his wife in the Russian translation, the accusation is not that he killed his brother, but that he abandoned his family:

«un omicida, sfuggito dall'ergastolo, non ha diritto di chiedere conto della propria famiglia» (Giacometti)

«у убийцы, сбежавшего из тюрьмы, нет права просить счет собственной семьи» [the word-based translation is ours] (u ubijcy, sbezhavshego iz tyur'my, net prava prosit' schet sobstvennoj sem'i, "The killer who escaped from prison has no right to ask for his own family's bill")

«у меня ты не имеешь права спрашивать отчета; ты нас бросил» [A.N. Ostrovsky] (u menya ty ne imeesh' prava sprashivat' otcheta; ty nas brosil, "You have no right to exact an account from me; you abandoned us").

It is interesting to note that in percentage terms the LSV "killer" prevails in the LSF "law" in the translation.

\section{DISCUSSION}

The sequence of changes in the Russian text can be traced from ideas about translation, through the changed title to the very end, in which Ostrovsky removes the final phrase "Legislatori, guardate!" ("Lawmakers, look!"), thereby making it more dynamic and dramatic.

The death of Corrado is also the result of his moral self-condemnation, an attempt to resolve a difficult civic and psychological situation. Corrado dies rebelling against the law. But Ostrovsky removes the final cue, so Corrado's motivation in the Russian translation is mainly moral, based on a love. He understands the degree of responsibility for what happened and does not want to become a criminal by destroying his family.

Thus, the examples given and the statistics obtained confirm the translator's intention - the main character is no longer shown as a murderer but a victim of his violent character. However, Corrado develops from a will-less victim of circumstances to a person who is able to manage his life and able to regain the rights of his family, albeit in a way such as suicide.

In Ostrovsky's interpretation, self-sacrifice wins in Corrado's soul, which is emphasised by the translation: the Russian text says about Corrado "он пожертвовал собой" (on pozhertvoval soboj, "he sacrificed himself"), whereas the original text does not have these words. Throughout the play, the evolution of Corrado is traced: Ostrovsky emphasises the awakening of humanity in him, respect for the human dignity, which encouraged him to make a heroic decision to sacrifice himself for the sake of his daughter's happiness.

The interest in Giacometti's play as a melodrama was connected with the artistic quest of a form for creating the heroic on the basis of a person's life in the environment. The melodramatic effect that is a significant part of Ostrovsky's poetics on his way to understanding the ways of penetration into the human psychology was corrected by the social analysis and an insight into a person's behavior and feelings that are explained by the environment and life conditions. Ostrovsky's attention to Giacometti's play was explained by an acute social and political conflict and a psychological elaboration of a character's image, the character that is endowed with moral qualities. In his translation, Ostrovsky emphasizes the psychology of an ordinary person and edits significantly the image of the main character diminishing the romantic stylistics pathos and transferring it into the reality key. Thus, there was a process of creative interaction of artistic principles of the national Russian theatre and the European one in Ostrovsky's work. This process led the playwright to creating the artworks that are remarkable for their acute moral and social problems and deep psychological discoveries. 


\section{REFERENCE LIST}

Giacometti P. Giacometti P. Teatro scelto di Paolo Giacometti: La morte civile dramma in 5 atti, V. 24. Libreria Sanvito, 1862.

Ostrovsky A.N. Complete works. In 12 volumes. A.N. Ostrovsky. Moscow: Iskusstvo, 1973-1979. V. 9, 1973.

Wierzbicka A. Semantics, Culture and Cognition: Universal human concepts in culture-specific configurations. Oxford University Press, 1992.

Wierzbicka A. Understanding Cultures Through Their Key Words: English, Russian, Polish, German, and Japanese. Oxford University Press, 1997.

Dahl V.I. Explanatory Dictionary of the Living Great Russian Language. In 4 volumes. Moscow: M.O. Volf Printing house, 1882, V. 4.

Italian-Russian Dictionary [Electronic resource]. ABBYY Lingvo, 1996-2016. URL: http://www.lingvo.ru/.

Kovalev V.F. Italian-Russian Dictionary [Electronic resource]. V. F. Kovalev. Zanichelli, 2001. 1 CD-ROM. 